\title{
Occupational Safety, Best Practices, and Legislative Review on Small-scale Mining in the Philippines
}

\author{
Jinky Leilanie Lu, MOH, $\mathrm{PhD}^{1}$ and Sophia Francesca Lu, MOS² \\ ${ }^{1}$ National Institutes of Health, University of the Philippines Manila \\ ${ }^{2}$ School of Labor and Industrial Relations, University of the Philippines Diliman
}

\begin{abstract}
Introduction. Small-scale mining (SSM) has been in the Philippines since the early 1900s and significant contributor to the local economy. SSM has contributed $14 \%$ of the country's total Gross Domestic Product and has a revenue share of about 19 billion pesos (380 million USD).
\end{abstract}

Objectives. This study aims to document mining occupational safety and health in SSM in the Philippines and identify best practices among miners and communities to reduce toxic chemical use in mining. It also aims to evolve laws and legislative measures on mining in the country as the basis for more aggressive policies and programs for SSM in the Philippines.

Methods. The data were based on gray literature, peer-reviewed journals, databases, government statistics, and secondary literature. Data were analyzed through critical appraisal on the impacts of mining in terms of occupational safety, mining issues, hazards, and disasters, environmental and health impact, as well as documentation of best practices in mining to reduce the use of toxic chemicals, and the current laws and legislations on mining in the Philippines.

Results. SSM or artisanal mining is categorized as part of the informal sector of the market economy. In the Philippines, the leading types of accidents in the mines are being hit by falling objects, suffocation from chemical fumes, and crushing injuries, exposure to intense heat, poor ventilation, vibration, dust, fumes, repetitive stress injury, intense noise, manual handling (e.g., lifting) of heavy machinery, and biological and chemical hazard. Occupational illnesses include skin diseases, emphysema, chronic obstructive lung disease, and hearing loss. Due to these risks, the Philippines has adopted mercury-free mining, cyanide reduction, and green and climate-smart mining. The use of borax in recovering gold from ore instead of mercury originated in the Philippines, which is now widely known as the mercury-free gravity-borax method adopted in Africa and Asia. The Philippines also has a plethora of laws covering mining as a whole. Developmental directives include enacting specific SSM laws and regulations, including a separate set of safety rules, and decentralizing the issue and control of SSM permits and licenses through local government units. Some noted legislative measures, Presidential Decrees, and Administrative Orders have been crafted to cover the safety net, equity, safety, and health for small-scale miners, among the most vulnerable working populations.

Discussion. Hazards and risks have been documented in SSM in the Philippines. However, the policies, legislation, and protective measures on SSM warrant more comprehensive coverage, implementation, and provision of social safety nets.

Conclusion. The study concludes that mining in the Philippines continues to be a problem as it produces adverse effects on workers' health, the community, and the environment. It is crucial to ensure the health and safety of mining workers, and all players and stakeholders must fulfill their respective roles. Governments and communities need to perform their regulatory and monitoring functions dutifully to build up their capacities to benefit mining communities that contribute much to the local economy.

Key Words: small-scale mining, Philippines, regulations and policies, mining-related diseases and injuries, occupational hazards in mining

Corresponding author: Jinky Leilanie Lu, MOH, PhD

National Institutes of Health, University of the Philippines Manila

623 Pedro Gil Street, Ermita, Manila 1000, Philippines

Email: jdlu@up.edu.ph 


\section{INTRODUCTION}

Small-scale mining (SSM) or artisanal mining (ASM) is categorized as part of the informal sector of the market economy. ${ }^{1,2}$ Worldwide, SSM and ASM have provided a source of livelihood for millions of mostly poor people across the globe and also served as the only means of livelihood for the people in rural communities. ${ }^{2-6}$ SSM refers to any single unit mining operation having an annual production of not more than 50,000 metric tons of ore and satisfying the following requisites: (1) working is artisanal, (2) either open case or shallow underground mining, (3) without the use of sophisticated mining equipment, (4) minimal investment on infrastructure and processing plant, (5) heavy reliance on manual labor, (6) owned, managed and controlled by an individual or entity qualified under existing mining laws, rules, and regulations. ${ }^{7}$ This type of mining has no or minimal mechanization or engineering techniques and uses rudimentary and conventional tools in exploration activities and drilling. ${ }^{8,9}$ As SSM usually involves smaller scale workrelated activities employed includes traditional pick-andshovel concerns. Furthermore, the mining practices of smallscale miners are mostly open-cast or quarrying operations. However, underground mining (stopping) methods can also be seen for the gold mines. Gold-processing techniques include the more sophisticated gold-recovery methods involving cyanide digestion followed by zinc dust or activated carbon precipitation. The crushed ores are collected and mixed with nitric acid to separate gold from other minerals such as silver and copper. Otherwise, the general method of gold recovery is by a gravity-concentration process using pans and sluice boxes. An amalgamation process is also applied, particularly in gold-rush areas. ${ }^{10}$ In addition, Mercury is used to removing gold by forming a mercury-gold amalgam, which then is heated to purified gold. This is where cyanide or mercury contamination of the environment can occur. ${ }^{11}$

There are various key players in the SSM sector, and these are individuals, families, groups, and cooperatives that belong to the informal sector of the market. All these various groups often suffer the most when detrimental effects arising from mining. Predominantly, ASM and SSM are associated with a range of persistent social and environmental challenges, including chronic poverty, land degradation, deforestation, mercury pollution, and river siltation. ${ }^{2}$

The Philippines' mining industry has been present since the early 1900s. The mining sector evoked national attention for its potential to contribute towards economic growth, job opportunities, and poverty alleviation. The mining industry has long been one of the significant contributors to the Philippines' economy as it is richly endowed with mineral resources. ${ }^{12}$ The Philippines is considered the fifth most mineralized country due to high gold, nickel, copper, and chromite. ${ }^{13}$ In 2019, exports of metallic, non-metallic minerals and mineral products were estimated at 4.38 billion USD. The top mineral exports were copper, gold, and nickel.
The significant exporters were Japan, Australia, Canada, and China. It was also reported that the mining industry provides employment opportunities. Around 190,000 workers are currently employed in the minerals industry. A total of 107.4 billion pesos is the contribution of the mining industry to GDP. ${ }^{14}$ Given the high economic impact of mining, SSM is often informal, making it unregulated and not well documented. This phenomenon increases the likelihood that small-scale miners be exposed to more potential health risks and hazards.

A study in the Philippines showed that industries such as agriculture, manufacturing, and mining have higher hazard risks, including exposure to harmful elements combined with strenuous physical work..$^{15}$ In the mining sector, due to tedious work and extreme environmental exposure, workers are exposed to varying degrees of and initially arises to problems in both individual and environment. ${ }^{16}$ Most commonly seen in the Philippines are high levels of silica dust during ore feeding and ball/rod mill operations, exposure to hydrogen cyanide, nitric acid, carbon monoxide at concentration considered dangerous to health. ${ }^{17}$

The Philippine government fully supports the development of its SSM industry since there is much potential and promise in this sector. ${ }^{18}$ This is manifested in the following developmental directives: enactment of specific SSM laws and regulations, including a separate set of safety rules; establishment of SSM unit within the Mines and Geoscience Bureau to support and regulate the sector; and decentralization of the issue and control of SSM permits and licenses through local government units (LGUs). Presidential Decree No. 1899 also establishes SSM as a new dimension in mineral development. ${ }^{7}$ Republic Act No. 7076, otherwise known as the "People's Small-Scale Mining Act of 1991, "- was also created for SSM programs and other related purposes. ${ }^{19}$

This study aims to document mining occupational safety and health in the SSM sector in the Philippines and identify best practices among miners and communities in reducing the use of toxic chemicals in mining. It also aims to give an evolution of laws and legislative measures on mining in the country as a basis for more aggressive policies and programs for SSM.

\section{MATERIALS AND METHODS}

This study used a review of literature and grey literature on the impact of SSM in the Philippines and exhaustive documentation of laws and best mining practices in the Philippines. The data obtained were analyzed through critical appraisal of the impacts of the mining sector in the Philippines in terms of mining issues, hazards, and disasters, its environmental and health implications, as well as documentation of best practices in mining to reduce the use of toxic chemicals, and the current laws and legislations on mining in the country. The critical appraisal looked at the search engine for keywords relevant to mining in the 
Philippines, legislation and policies on mining, hazards and diseases documented from mining operations or possibly associated with mining, and best practices of specific LGUs on SSM. Then analytic constructs were developed. These constructs were the basis of the themes laid out in the discussion of this paper. Two expert opinions looked again at the analytical constructs. They proceeded with the elaboration of the paper focusing on occupational safety, best practices, and legislative review of SSM unique in the Philippines.

\section{RESULTS AND DISCUSSION}

As the mining sector plays a vital role in the Philippines due to its economic advantage and work opportunities, it is crucial to look for the betterment of the condition of these workers. SSM causes health hazards that increase the exposure of individuals and communities to different diseases and injuries. The mining process, if not sustained, can cause detrimental consequences on land degradation, contamination of soil and bodies of water, and health issues to humans living within the mining vicinity.

\section{Mining Issues, Hazards, and Disasters}

Mining is one of the most dangerous human activities, whether large-scale industrial mining or small-scale ASM. $^{20-22}$ The mining activities constitute multiple parts such as exploration, construction, operation, maintenance, expansion, abandonment, decommissioning, and reposing of mine that impacts social and environment in both positive and negative, directly or indirectly. ${ }^{23}$ These injuries and fatalities may include mishappening such as road accidents in remote mining locations, electrocution or machinery malfunctions, catastrophic events that inflict loss of life, gas explosion or cave-ins, and even health problems due to exposure to harmful substance. ${ }^{21}$ As Rebello et al. (2021) said, at every mining location, the miners are either exposed to hazardous chemicals, or the surrounding community near the mining location is at risk of chemical intoxication due to mining. ${ }^{24}$

In a study in the Philippines, the leading types of accidents in the mines are being hit by falling objects, suffocation from chemical fumes, and crushing injuries. ${ }^{25}$ Other occupational health hazards include exposure to intense heat, poor ventilation, vibration, dust, fumes, repetitive stress injury (RSI), intense noise, manual handling (e.g., lifting) of heavy machinery, and biological and chemical hazard. ${ }^{25}$ In underground mining, poor ventilation causes respiratory failure that may lead to brain malfunction or even death. As SSM usually has more inferior structures, the increase in the risk of a tunnel collapse or subsidence is not remote. Also, small-scale miners are known to operate following their convenience, thus posing risks on the possible adverse environmental impact. This makes the mining site more prone to landslides and loss of ecosystems. ${ }^{26}$ Longterm exposure in the mining industry to various factors, such as vibration, noise, dustiness, and unfavorable microclimate, is hazardous to every miner's health, manifested by elevated general and occupational morbidity and a higher rate of biological aging..$^{10}$ As such, there is also a need to study the accompanying environmental hazards in mining operations.

\section{Environmental Impacts}

The impact of mining on the environment is vast and affects almost if not all sectors of the environment. ${ }^{24}$ The construction of infrastructure and associated building leads to disturbance of ecosystem leading to soil erosion, deforestation, habitat loss, and decline in the species present at the area. ${ }^{24}$ Since the mining activity is a continuous process, the constant generation of acid or alkalis occurs, and the often-incessant burden is added to water bodies of mining areas. The drain out of these minerals to aquatic environments has a drastic impact on the marine environment.

Coehlo, Teixeira, and Gonçalves (2011) enumerated some adverse environmental effects such as contamination of soils and aquatic sediments, landscape alteration, subsidence, and changes in vegetation. ${ }^{27}$ These eventually result in surface water pollution, air pollution, groundwater degradation, and loss of productive land. ${ }^{27}$ Mining also has health impacts. In processing gold, for example, cyanide is being used to extract it from the ore. The residue of the solution causes contamination to both water and soil. This renders the streams to be acidic, which destroys aquatic life. The discharge of mine effluent and seepage from tailings and waste rock impoundments cause water pollution. ${ }^{28}$ The significant mining impacts on water quality are acid mine drainage (ARD), heavy metal contamination and leaching, processing chemicals pollution, and erosion and sedimentation. All these severely degrade water quality killing aquatic life and smothering watershed vegetation. Overall, this makes water virtually unusable. ${ }^{28}$ Toxic heavy metals such as lead, zinc, copper, arsenic, mercury, and cadmium are released from acid-mine drainage. ${ }^{28}$ They are leached out and carried by acidic water and are deposited in a more or less level land. ${ }^{28}$ This can be acted upon by bacteria and methylated. ${ }^{29}$ When in organic form, the methylated heavy metal can readily enter the living organisms and become deposited in their tissue, and while in their tissues, metals can interfere with normal metabolic processes. ${ }^{29}$

One of the contributors to the geomorphological changes in mining sites is deforestation. Due to the informal nature of ASM and SSM, no responsibility is held for the proper and safe closure of mining sites. With that, damaged and chemical-contaminated soil and water bodies are the main problems. Deforestation also occurs to accommodate mining sites; however, it can cause landslides, poor water quality, a decrease of biodiversity, and poor soil quality. ${ }^{30}$

\section{Health Impacts and Occupational Hazards}

The traditional picture of the working conditions in mining and quarrying is that the work is physically demanding and dangerous due to heavy and awkward loads, unstable underground structures, heavy tools and 
equipment, significant accident risks, exposure to toxic dust and chemicals, heat, and cold. The adverse working conditions can cause a variety of occupational diseases. ${ }^{31}$ This is the same with Winmore and Tafadzwa's (2014) findings wherein mining tools and equipment and exposures to dust, heat, and humidity were the perceived hazards causing health problems among small-scale miners. ${ }^{32}$ Thus, miners become physically unfit to work, which brings a day without a job thus a day without pay or income. ${ }^{32}$ Rebello et al. (2021) also mentioned that various stress factors are often faced by miners every day. ${ }^{24}$ This includes thermal stress, musculoskeletal disorders, chemical hazards, vibration, UV exposure, coal dust, and noise. This can lead to occupational diseases and injuries such as pneumoconiosis (a lung disease caused by excessive dust inhalation), lacerations, cuts, and crashes, asbestos mesothelioma (severe fibrosis), silicosis (fatal lung disease), skin diseases, emphysema, chronic obstructive lung disease and hearing loss. ${ }^{24,32}$ In a study in Ghana assessing workers' knowledge and views on the hazard of gold mining, results showed that most $(63.3 \%)$ workers had insufficient understanding of occupational health and regulation. ${ }^{16}$

\section{Accidents}

Thousands of miners die in accidents every year, and many more are injured, especially in coal and hard rock mining. In a sub-Saharan African study, the lower extremities were the common body parts likely to be injured among SSM workers. Falling was the most common accident, while the most common types of injuries were lacerations, burns and scalds, contusions, and abrasions. ${ }^{33}$ Similar to that, in Turkish open-cast mines, surface installations, workshops, and mining areas showed the highest probability of serious non-fatal accidents occurring in transport and manual handling. ${ }^{22}$ Fractures and contusions are the most frequently occurring injuries in SSM, with the collapse of the mine pits, drowning, crushing, and falls the most commonly reported cause of accidents. $^{22,34}$ In addition, Duarte et al. (2019) found that mining equipment also brings forth accidents. ${ }^{35}$ The study also found that proper training programs and other safety measures decrease these hazards' risk. ${ }^{35}$ Current numbers may be underestimated because informal mining (artisanal, illegal, and SSM), which generally has worse working conditions, is not represented in national records.

Mining disasters have also been reported to occur in certain areas in the Philippines, as shown in Table 1.

\section{Cyanide Exposure in Mining}

Cyanide exposure is one of the risks in SSM. Cyanide has been used worldwide to extract gold and silver as it helps separate metals from ore. ${ }^{41,42}$ Singly or in combination with other chemicals, cyanide can be lethal and cause adverse impacts to health and the environment. ${ }^{43,44}$

In the Philippines, most gold mines are known to use cyanide solutions to extract gold. Cyanide is a toxic substance as it blocks the transfer of oxygen from the blood to the body tissues, which leads to the accumulation of lactate in the body. This substance comes into contact with miners through skin absorption or inhalation. ${ }^{45} \mathrm{~A}$ study in Ecuador found a high cyanide concentration in river surface due to residue of mercury-contaminated tailing from 87 gold processing centers in southern Ecuador. ${ }^{46}$

In a study conducted in small-scale mines exposed to cyanide in Camarines Norte, Philippines, children ages 17 years old and below experienced cough, wheezing, shortness of breath. Three children had pneumonitis, and 2 with pulmonary tuberculosis. About $65 \%$ of the children had lead levels above $10 \mathrm{ug} / \mathrm{dl}$, with the highest value at $25 \mathrm{ug} /$ d1. ${ }^{47}$ Meanwhile, a cross-sectional epidemiological study in Burkina Faso showed mean blood lactate levels were significantly higher in miners using cyanide $(4.7 \mathrm{mmol} / \mathrm{L}$, 95\% confidence interval (CI) $3.8-5.6 \mathrm{mmol} / \mathrm{L})$, compared to non-cyanide using miners $(3.4 \mathrm{mmol} / \mathrm{L}, 95 \% \mathrm{CI} 2.9-3.7$ $\mathrm{mmol} / \mathrm{L})$ and other community members not involved in mining activities $(2.8 \mathrm{mmol} / \mathrm{L}, 95 \%$ CI $2.4-3.2 \mathrm{mmol} / \mathrm{L})$. The study found that the use of cyanide is associated with negative health effects. ${ }^{48}$ Basu et al. (2015) such as psychosocial, cardiovascular, respiratory, and sexual risks, nutritional, water and sanitation issues, malaria, upper respiratory tract diseases, especially pulmonary tuberculosis and silicosis, and skin diseases, and injuries and accidents. ${ }^{22}$

Table 1. Mining disasters reported in Benguet, Philippines

\begin{tabular}{|c|c|}
\hline Municipality & Mining Disasters \\
\hline \multirow[t]{2}{*}{ Itogon } & $\begin{array}{l}\text { - A miner died of suffocation due to gas poisoning inside the mining tunnel at Loacan, Antamok, Itogon, Benguet. The mining } \\
\text { site was a former operation site of Benguet Corporation, an abandoned mining site. It later opened again to small-scale miners } \\
\text { who were required to sell their produce to the company (Quitasol, 2010).36 } \\
\text { - Six miners were trapped inside the tunnels because the walls collapsed due to flooding. Only three were rescued (Quitasol, } \\
2010){ }^{36} \\
\text { - Fourteen miners were trapped in an underground in a mine in Itogon. The Cordillera Peoples Alliance has blamed the Itogon } \\
\text { tragedy on the Benguet Corporation (MAC, 2008). }{ }^{37}\end{array}$ \\
\hline & $\begin{array}{l}\text { - In 2018, when Typhoon Mangkhut (Ompong) struck the Philippines, it buried around } 100 \text { miners alive due to massive } \\
\text { landslides. It took a whole week before all bodies buried were retrieved from the } 20 \text { feet mud believed to be caused by } \\
\text { tunneling activities of the AGSM sector (Manza, 2020). }\end{array}$ \\
\hline Mankayan & $\begin{array}{l}\text { - A section of a mining town in Mankayan was declared a danger zone due to landslides after a few days of heavy rainfall (Ramo, } \\
\text { 2009). }{ }^{39}\end{array}$ \\
\hline
\end{tabular}




\section{Mercury Exposure in Mining}

SSM is the most significant contributor to mercury emissions, contributing to about $35 \%$ of emissions globally. ${ }^{49}$ Mercury is used for gold extraction in artisanal and smallscale gold mining. ${ }^{50}$ This chemical is commonly used in gold extraction as it is relatively cheap, easily accessible, and effective in extracting gold. ${ }^{51}$

In SSM in Western Mindanao, workers were found to be exposed to high levels of mercury. Gastrointestinal complaints of the workers were significantly associated with elevated hair methylmercury levels. ${ }^{52}$ Moreover, the study showed a relationship between elevated diastolic blood pressure and gastrointestinal complaint. ${ }^{52}$ Furthermore, a study by Samaniego et al. (2020) in an abandoned mercury mine area in Puerto Princesa, Philippines, showed that total $\mathrm{Hg}(\mathrm{THg})$ concentrations found in soils $(0.04-67.5$ $\mathrm{mg} \mathrm{kg}-1$ ), mine waste calcines (52.7-924.2 mg kg-1), river sediments (1.8-119 $\mathrm{mg} \mathrm{kg}-1)$, and marine sediments (0.04-12.7 mg kg-1) were elevated compared to the global background of $0.045-0.16 \mathrm{mg} \mathrm{kg}-1 .{ }^{53}$ The presence of high concentration was due to the released $\mathrm{Hg}$ from the mine operation. This gives an overview that residents within the vicinity may be affected by $\mathrm{Hg}$ exposure..$^{53}$ In 2017, it was reported that chronic mercury poisoning occurred in two barangays in Palawan, Philippines, and both are near an abandoned mercury mining site. The residents were found to be suffering from chronic mercury poisoning due to eating contaminated seafood. ${ }^{54}$ Further, a study in Mindanao found that mercury mining wastes contaminate soil quality, crops, and fish. It was found that $\mathrm{mMcHg}$ intake within the vicinity was almost three times the JECFA PTWI of $1.6 \mu \mathrm{g} / \mathrm{kg}$ bw..$^{55}$ Another reason for the high mercury contamination is the unregulated nature of SSM. In 1997, a study conducted in Itogon-Suyoc Mine, Philippines, showed various symptoms of occupational-related health risks among mine workers exposed to mercury, such as cough and breathing difficulty being abnormally high among exposed workers. ${ }^{25}$ Other prevalent health symptoms among the exposed workers were excessive sweating, hypertension, and constant muskuloskeletal pain. ${ }^{52}$ Despite these, the government lacks specific regulation and monitoring system for safety and health among small-scale miners in the Philippines even though this sector has contributed.

\section{BEST PRACTICES ON MINING IN THE PHILIPPINES}

\section{Mercury Reduction}

In general, the gold processing method used in the Philippines is the technique called whole-ore amalgamation. ${ }^{56}$ This method requires mercury when the ore and water mixtures are milled to recover the gold as mercury forms an amalgam with gold. The amalgam is blowtorched to allow the mercury to evaporate and thus recovering the gold from the amalgam. ${ }^{56}$ However, in recent years, the small-scale miners in Benguet have had a mercury-free method of extracting the gold from the ores. Incorporating borax in mining processing started thirty years ago in Benguet, Philippines as a miner discovered that using borax can quickly recover gold. ${ }^{57}$ The mercury-free gravity-borax method (GBM) employs the same equipment as whole-ore amalgamation except that the added chemical is borax instead of mercury. ${ }^{56}$ Borax usage in ASGM is expected to be less toxic because ASGM miners have very low exposure to the said chemical. Since boron vaporizes at an immensely increased temperature, no dust and evaporation are produced. Boron also does not penetrate the skin, unlike mercury. ${ }^{56}$

The adoption of mercury-free gold mining protects the male SSM miners themselves and the women and children involved in processing the gold ores. ${ }^{58}$ Moreover, more gold is recovered with this method, the cost is much less, and it is readily available. ${ }^{57}$ This was also shown in a study in Kalinga that introduced GBM to the small-scale miners there. ${ }^{56}$ The same study introduced small-scale miners in Camarines Norte, but few adopted the technique. This shows how GBM, a far safer and eco-friendly alternative of wholeore amalgamation, is not yet well-known throughout the Philippines, although it originated in the country.

Efforts to also introduce GBM to other countries were attempted. In Sorata, Bolivia, the process of GBM yielded more gold when used by medium-scale miners, and the miners later adopted it; moreover, healthcare providers were also trained in a 2-day seminar about amalgamation and its alternative $(\mathrm{GBM}){ }^{59}$

Another mercury-free method in gold processing is the gravity concentration technique. A sluice box covered with jute, carpet, or corduroy cloth is needed to separate the gold grains from the ore-water mixture. ${ }^{60}$ The material covering the sluice box is washed to retrieve the gold further. ${ }^{60}$ This is practiced in the Philippines and other countries like in Guianas, South America, wherein the recovery rate of gold using the method was studied and resulted in a strong recovery rate of $91 \% .{ }^{61}$

\section{Cyanide Reduction}

The use of cyanide in gold processing is also prevalent in the Philippines. The process of cyanidation includes carbonin-leach, carbon-in-pulp, and heap leach methods in which cyanide is involved in the dissolution of gold. The carbonin-leach method consists in subjecting the gold ore through a zinc oxidation process to recover the gold, which takes 15 days to complete. On the other hand, the carbon-in-pulp technique includes the addition of lime, water, and grounded gold ore to a cyanide solution. Cyanide is then added after 8 hours, followed by activated carbon after another 8 hours. Heap leaching is a method of processing mine tailings where cyanide is added after two days. In Benguet, carbon-in-leach and heap leaching are used. ${ }^{60}$ In Australia, cyanide-free gold recovery was developed. This involves using thiosulphate, which is safer and has less negative environmental impact, 
as an alternative to cyanide to dissolve the gold. ${ }^{62}$ The gold yield in a cyanide-free method is comparable to when cyanide is used in some cases; however, better yields are observed when preg-robbing ores are involved. Preg-robbing ores are natural carbon substances that do not absorb the goldthiosulphate complex. ${ }^{63}$ A recent project testing the gold recovery rate of thiosulphate was conducted in Menzie, Western Australia. This project aimed to reach the goal of an $80 \%$ recovery rate, but the yield was $85 \%$ when the cyanide alternative was used. ${ }^{64}$

\section{Lead and Silica Reduction}

Silica is a chemical compound found in ores, and its dust particles can be generated through mechanical methods of processing the ores in SSM. These dust particles are relatively small and thus can be easily inhaled. ${ }^{65}$ In reducing silica dust exposure, technologies such as local exhaust ventilation, process enclosure, wet techniques, and elimination or substitution should be employed. ${ }^{66}$ Lead also has the same case as silica when ground mechanically, and this had been linked to lead poisoning that happened in Nigeria in the 2010s that claimed lives of children. ${ }^{67}$ Thus, to reduce the exposure for silica and lead through mechanical methods, the spray misting way was studied in Nigeria. The study results showed that when the spray misting technique was used instead of the dry mechanical method, it led to a $95 \%$ reduction in lead exposure and an $80 \%$ reduction in silica exposure. This method was the first intervention to be made to decrease silica and lead exposures in ASGM. ${ }^{68}$ This intervention also led to a $32 \%$ decrease in the blood lead levels of the 61 respondents of the study in the 19 months duration of the project. ${ }^{69}$ This method is also being promoted in the Philippines for the safeguard of small-scale miners.

\section{Green and Climate-Smart Mining}

The Climate-Smart Mining initiative is designed for developing countries with rich mineral deposits to help these nations cope with the increasing demands for minerals towards clean energy transition by reducing adverse environmental impacts through reducing "environmental and climate footprint."There is a growing demand for clean energy technologies as the world shifts to a more environmentfriendly energy source. The "Minerals for Climate Action: "The Mineral Intensity of the Clean Energy Transition," report by the World Bank Group estimated that there would be high demands for minerals such as graphite, lithium, and cobalt for the same reason, thus opening the need for Climate-Smart Mining Practices. ${ }^{70}$

The Philippines is also moving towards adopting green technologies for mining. A project by the Department of Science and Technology - Cordillera Autonomous Region (DOST-CAR) and University of the Philippines Diliman (UPD) in Itogon, Benguet has an alternative to traditional gold processing uses mercury or cyanide as chemicals. This is the "enhanced gravity concentration flotation-extraction process" that is more eco-friendly by ensuring that the wastes generated from the sites are "safe and non-pollutant". ${ }^{71}$ Aside from Benguet, green mining pilot plants were also set up in Jose Panganiban in Camarines Norte, Cabadbaran in Agusan del Norte and Nabunturan in Compostela Valley which are areas known with SSM. ${ }^{72}$

\section{Safety Practices}

A study by Mones (2018) in areas of Benguet, Camarines Sur, Agusan del Sur and South Cotabato, provinces of the Philippines, showed the saflaborety practices of SSM miners. ${ }^{73}$ Two areas in Benguet were studied, and it was shown that first aid safety training was conducted to miners in the area. In one area of the study, nurses were said to be stationed at the site. Safety tools such as safety boxes, breakers, and control sites were also available in the SSM. In South Cotabato, Philippines, rescue operations offered by LGU were far from the area of study; thus, miners there have associations called 'minero unity' to rescue miners during disasters or accidents, and safety meetings are conducted every month. In Agusan del Sur, medical bills are handled by the contractors in times of an accident. A Buddy system is also implemented for workers who go in and out of the tunnel.

\section{LGU Efforts towards Best Practices}

RA 7160 (Local Government Code of 1991) was signed in 1991, which emphasizes that the LGUs are autonomous in order "to enable them to attain their fullest development as self-reliant communities and make them more effective partners in the attainment of national goals" (RA 7160, 1991), and thus subsequently giving the LGUs to regulate the SSM industry within their respective areas. ${ }^{74}$

The issue of hazardous chemicals used in SSM is actively addressed. The recent actions are in 2019 as mercury use in SSM in South Cotabato was banned per EO 20 s. 2019 "Prohibiting the Use of Mercury in Gold Ore Processing in T'boli, South Cotabato." The LGU, on the other hand, promotes the use of the gravity method in place of mercury in gold extraction..$^{75}$ In Itogon, Benguet, cyanide use is barred following environmental problems. ${ }^{76}$ Two years prior, the cyanide used in mining activities in Itogon was suspected of having leaked in a river in the said area, causing the water in the river to turn color blue. ${ }^{77}$ As a result of this, mercury use in SSM has been banned under the power of EO 79 signed in 2012.

A study conducted in 2013 introduced GBM in Camarines Norte; however, very few adopted this mercuryfree method of gold processing, and mercury use was still evident in the province. ${ }^{56}$ Following this, in 2016, the LGU Camarines Norte, Philippines collaborated with an NGO, Ban Toxics, and signed a memorandum of understanding (MOU) to begin activities regarding technical and health training to facilitate the transition to mercury-free use in gold processing and in 2018 mercury use was being monitored in Camarines Norte. ${ }^{78,79}$ 
In 2011, 19,000 children were estimated to be working at 45 small-scale mines in the Philippines, according to the ILO. ${ }^{80}$ In Camarines Norte, children 10-17 years old are highly engaged in compressor mining because of poverty or school allowance. ${ }^{73}$ Compressor mining is done by digging holes in shallow waters to recover the gold ores that may be trapped in there. The miners are set to descend in the waters with a hose in their mouths attached to a compressor to supply air when the miners are below the waters. ${ }^{60}$ The Camarines Norte LGU, in partnership with ILO, ended child labor in this province. ${ }^{81}$ Also, a preventive measure in South Cotabato included using the ID system in miners to alleviate child labor and mining accidents. ${ }^{82}$ Furthermore, compressor mining is long banned in the Philippines under the power of EO 79 .

The other efforts of the LGUs in SSM include the relocation of the mining sites to safer places that are not landslide and flood-prone areas (South Cotabato, Philippines), banning open-pit mining (Zamboanga de Norte, South Cotabato in the Philippines), setting up Minahang Bayan Center (South Cotabato) for easier permit processing, and formation of the task force against illegal mining for accident prevention and control environmental concerns (Benguet)..$^{82-84}$

\section{Legislative measures}

The 1987 Philippine Constitution Article XII Section 2 states that "the exploration, development, and utilization of natural resources shall be under the full control and supervision of the State." Thus, SSM being an industry that uses the natural resources of the Philippines, is strictly regulated. ${ }^{85}$ The earliest attempt to regulate SSM in the Philippines was during the passing of PD 1899 (Establishing Small-Scale Mining as a New Dimension in Mineral Development) in 1984. By this law, permits or licenses that are renewable for two years are issued to small-scale miners to assist in generating profits, especially to workers in rural areas provided that "they are holders of valid and existing mining rights, who have subsequently complied with existing mining laws, rules and regulation" before the passing of the PD $1899 .{ }^{60}$

This is followed by the Republic Act No. 7076, which created the "Minahang Bayan." However, the implementing rules and regulations under DAO 1992-34 state that all activities outside "Minahang Bayan" are to be powered by the PD 1899. ${ }^{73}$ In 1995, RA 7942 ("The Philippine Mining Act") was signed. Included in its implementing rules and regulations (as contained in Department of Environment and Natural Resources (DENR) Administrative Order No. 2010-21), local ordinances and executive issuances on mining must be consistent with the Philippines Constitution. The Philippine Mining Act Law provides a regulatory and institutional framework for a mining operation, hoping that foreign capital is brought into government. It also states community consultation, local government empowerment, concern for indigenous communities, equitable benefits sharing. ${ }^{86}$ Table 2 summarizes the relevant laws affecting the mining industry in the Philippines.

The creation of RA 7076 in 199 raised conflicts against the PD 1899 between the implementing government bodies regarding its implementation and regulation. There was no repeal made for the following laws succeeding PD 1899, not even RA 7942. Thus, several attempts were made to "harmonize" the two laws until EO 79 (Institutionalizing and Implementing Reforms in the Philippine Mining Sector Providing Policies and Guidelines to Ensure Environmental Protection and Responsible Mining in the Utilization of Mineral Resources) was signed in 2012, establishing that SSM should follow the RA 7076. ${ }^{97}$ However, People SmallScale Mining Act of 1991 is considered to be a failure in attaining its objectives. This happened due to multiple reasons such as policy overlaps, confusion among stakeholders, poor compliance and enforceability issues, lack of capacities of regulators and agencies to provide necessary support infrastructure. Furthermore, issues related to implementation laws were discussed by Clemente (2019). ${ }^{98}$ Her study stated four (4) significant issues related to the implementation, and these are (1) circumvention of permits, (2) interfacing with LGUs, (3) delays in the declaration of IP claims, (4) institutional issues of NCIP. ${ }^{98}$

It was suggested that in attaining the set objectives, a more explicit direction is needed, sounder regional-based strategies, well-formulated roadmaps must be established parallel to legal frameworks, and comprehensive profiling of sector per community, municipal, and provincial level. ${ }^{18}$ United Nations Development Programme stipulated that mining-related strategies and activities should be included in the development plans. This includes integration into national and regional development plans, land use plans, macroeconomic plans, fiscal revenue projections, infrastructure plans, public service delivery plans, human resource development, and education sector policies. ${ }^{99}$

According to ICLG (2021), the recent political development affecting the mining industry is the conservative position on mining and the continuous implementation of a moratorium on new mineral agreements. ${ }^{94}$ DENR Administrative Order No. 2018-13 has lifted the suspension on accepting, processing, and approving applications for exploration permits. While DENR Administrative Order No. 2107-10 imposes a ban on open-pit mining. ${ }^{94}$

The Philippines has signed several treaties and conventions. With International Labour Organization, the Philippines ratified the C176 (Safety and Health in Mines Convention), C138 (Minimum Age for Admission to Employment and Work), and C182 (Work Forms of Child Labour), among others. ${ }^{73}$ On the other hand, Minamata Convention was also signed by the Philippines in 2013. This convention was endorsed following the disaster in Japan. The Minamata bay was contaminated by hazardous chemicals containing methylmercury from 1932 to $1968 .{ }^{100}$ 
Table 2. Summary of relevant laws affecting the mining industry in the Philippines

\begin{tabular}{ll}
\multicolumn{1}{|c}{ Law } & Name \\
Republic Act & Philippine Mining A \\
No. 7942 &
\end{tabular}

No. 7942
Name Act

(n)

"All mineral resources in public and private lands within the territory and exclusive economic zone of the Republic of the Philippines are owned by the State. It shall be the responsibility of the State to promote their rational exploration, development, utilization, and conservation through the combined efforts of government and the private sector to enhance national growth in a way that effectively safeguards the environment and protect the rights of affected communities" (RA 7942, 1995). ${ }^{87}$

\begin{tabular}{ll}
\hline $\begin{array}{l}\text { Presidential } \\
\text { Decree No. } 442 \\
\end{array}$ & Labor Code of the Philippines \\
\hline $\begin{array}{l}\text { Republic Act } \\
\text { No. } 7160\end{array}$ & Local Government Code of 1991 \\
\end{tabular}

This PD governs the Philippines' employment practices and labor relations (DOLE, n.d.). ${ }^{88}$ This law also states that hazardous occupation is not allowed for 18 years old and below and that the minimum age requirement for working is 15 years old (Human Rights Watch, 2015). ${ }^{89}$

This law gives autonomous powers to local government units "to enable them to attain their fullest development as self-reliant communities and make them more effective partners in the attainment of national goals." This also gives LGUs the role of promoting and regulating SSM (RA 7160, 1991). ${ }^{74}$

\begin{tabular}{ll}
\hline Republic Act & Toxic Substance and Hazardous \\
No.6969 & and Nuclear Wastes Control Act
\end{tabular}

"It is the policy of the State to regulate, restrict or prohibit the importation, manufacture, processing, sale, distribution, use and disposal of chemical substances and mixtures that present unreasonable risk and/or injury to health or the environment; to prohibit the entry, even in transit, of hazardous and nuclear wastes and their disposal into the Philippine territorial limits for whatever purpose; and to provide advancement and facilitate research and studies on toxic chemicals" (RA 6969, 1990). ${ }^{90}$

\begin{tabular}{ll}
\hline $\begin{array}{l}\text { Republic Act } \\
\text { No. } 8749\end{array}$ & Clean Air Act \\
\hline $\begin{array}{l}\text { Republic Act } \\
\text { No. } 9003\end{array}$ & Ecological Solid Waste \\
& Management Act \\
\hline $\begin{array}{l}\text { Republic Act } \\
\text { No. } 8371\end{array}$ & Indigenous Peoples' Rights Act \\
\end{tabular}

This act aims to achieve and maintain quality air for Filipinos through comprehensive air management policies and programs (DOH, n.d.). ${ }^{91}$

RA 9003 is an act that aims to protect the public's health and the environment through a "systematic, comprehensive and ecological waste management program" (Aquino, Derequito, \& Festejo-Abeleda, 2013). ${ }^{92}$

No. 8371

This act recognizes and promotes all the rights of Indigenous Cultural Communities/ Indigenous People (ICC/IP) per the 1987 constitution (RA 8371, 1997).93 This protects the land of ICC/IPs in activities such as mining by acquiring their informed consent first (ICLG, 2021). ${ }^{94}$

\begin{tabular}{ll}
\hline Republic Act & People Small-Scale Mining Act \\
No. 7076 & of 1991
\end{tabular}

This legislation aims to generate more employment opportunities in the mining sector and provide an equitable sharing of the nation's wealth and natural resources by implementing the People's Small-Scale Mining Programme (Granadillos \& Parafina, 2020). ${ }^{17}$

\begin{tabular}{ll}
\hline DENR & Small-Scale Mine Safety Rules and \\
Administrative & Regulations \\
Order 1997-30 & \\
\hline
\end{tabular}

Executive Institutionalizing and Implementing

Order No.79 Reforms in the Philippine Mining Sector, Providing Policies and Guidelines to Ensure Environmental Protection and Responsible Mining in Utilization of Mineral Resources

\begin{tabular}{ll}
\hline DENR & Revised Implementing Rules and \\
Administrative & Regulations of RA 7076 \\
Order 2015-03 &
\end{tabular}
This AO created the rules and regulations for small-scale mining. Under this, safety inspections and training shall be provided for the SSM workers (Mones, 2018). ${ }^{73}$

The passing of EO 79 as legislation had put the SSM industry as a responsible sector by banning mercury and compression mining. This law also limited the natural resources that can be mined to gold, silver, and chromite only (DOST-PCIEERD, 2018). ${ }^{71}$

This is the revised implementing rules and regulations for EO 79. Under this $\mathrm{DAO}$, contracts shall be awarded by the Provincial/City Mining Regulation Board (P/CMRB). This also limited the Minahang Bayan for six years and established that the qualification for granting mining contracts are groups of small-scale miners or cooperatives. Moreover, a centralized custom mill shall be required in Minahang Bayan sites (Basilio, 2015). ${ }^{95}$

\begin{tabular}{ll}
\hline Republic Act & An Act Strengthening Compliance \\
No.11058 & with Occupational Safety and Health \\
& Standards and Providing Penalties for \\
& Violations thereof \\
\hline DENR-MGB & Clarificatory Guidelines for \\
Memorandum & establishing the Contingent Liability \\
Order No. & and Rehabilitation Fund for Dredging \\
2020-004 & Projects/Activities Pursuant to the \\
& DPWH-DENR-DILG-DOTR Joint \\
& Memorandum Circular (JMC) No. 1 \\
& Series of 2019. \\
\hline
\end{tabular}

RA 11058 aims to provide quality welfare and well-being to employees by preventing workplace-related accidents, deaths, injuries, and illnesses through the promotion of occupational safety and elimination of health hazards (BWC-DOLE, n.d.). ${ }^{96}$

This was a memorandum passed during the pandemic concerning COVID-19 wherein protocols such as "personal profiling, physical distancing, personal hygiene, and sanitation" are required for workers in SSM; moreover, mining contractors or permit holders are to issue personal protective equipment and other medical supplies needed by the workers necessarily (ICLG, 2021). ${ }^{94}$ 
The treaty aimed "to protect the human health and the environment from anthropogenic emissions and releases of mercury and mercury compounds." ${ }^{101}$ However, as discussed above, the use of hazardous compounds (mercury, cyanide, etc.), exploitation of child labor in some areas, and the overlooking of safe working conditions in the SSM industry are still prevalent. This shows how the SSM industry still needs attention from both the national and LGUs. Existing laws are combatting these issues; however, there is a need to implement these legislations strictly.

The mineral sector must continue to increase efforts in making its operation sustainable. The best way is to approach the problems holistically. There should be proactive management and continuous engagement between and among all stakeholders throughout the life cycle of mining projects. Sustainability emphasizing institutional leadership and technological innovation, intra-and intergenerational equity that aims to sustain mineral sources in the longterm horizon. Specifically, for ASM and SSM, it is vital to take note of sustainability issues related to mining, such as risks associated with using mercury, capacity to internalize environmental and social costs, coexistence with large mining companies, child labor exploitation, technical skills, and access to technology. ${ }^{102}$

There is also a mining and environmental plan, which addresses both the technical and social issues. In this framework, sustainable development is sought, such as improved metal recovery and less metal present in waste material, planning for mine closure, public perception and community issues, and public reporting of a corporation's environmental performance. ${ }^{103} \mathrm{In}$ addition, the principle under this plan should uphold measures and strategies including minimizing the depletion of non-renewable natural resources, 'polluter pays' principle, resource efficiency, full costing and environmental impact assessment, FPIC principle, public participation, transparency and accountability, and multistakeholder partnerships in the public interest. ${ }^{99}$

\section{CONCLUSION}

Several occupational health hazards and problems are identified in this study to exist in mining. Also, mining produces adverse impacts on the environment. If unmitigated, continuous degradation of the environment leads to more health hazards to the workers and people residing near the mining area.

This study has shown some of the best practices in mining in the Philippines and internationally, such as mercury reduction or replacement, cyanide reduction, silica reduction, and safety techniques. The local government efforts were also shown on safeguarding health and safety among miners and the environment and laws and legislative measures in the Philippines to promote sustainable and safe mining.

There is a need to ensure the health and safety of mining industries, where all stakeholders must fulfill their respective roles. Government should come up with policies and programs coupled with regulatory framework and monitoring. Communities, on the other hand, need to build up their capacities for OSH in SSM. Also, access to a broader range of related information about mining should be made available.

Together with the United Nations policies in pursuit of sustainable development and the consensus expressed at international conferences during the last decade, these trends have deepened social awareness and set the stage for enhanced social responsiveness from all sectors of society. However, the government can only do much if the operation of SSM is not formalized.

\section{Statement of Authorship}

Both authors participated in the collection and analysis of data and approved the final version submitted.

\section{Author Disclosure}

Both authors declared no conflicts of interest.

\section{Funding Source}

This study was implemented through the National Institutes of Health, University of the Philippines Manila.

\section{REFERENCES}

1. Hentschel T, Hruschka F, Priester M. Artisanal and Small-Scale Mining: Challenges and Opportunities [Internet]. London: International Institute for Environment and Development and WBCSD; 2003 [cited 2020 Dec]. Available from: https://pubs.iied. $\mathrm{org} /$ sites/default/files/pdfs/migrate/9268IIED.pdf?.

2. Hirons M. How the Sustainable Development Goals Risk Undermining Efforts to Address Environmental and Social Issues in the Smallscale Mining Sector. Environ Sci Policy. 2020 Dec;114:321-8.

3. Barillo DJ. Diagnosis and Treatment of Cyanide Toxicity. J Burn Care Res. 2009;30:148-52.

4. National Occupational Health and Safety Commission. Cyanide Poisoning - First Aid and Medical Treatment [Internet]. Perth: Department of Consumer and Employment Protection, Government of Western Australia; 2009 [cited 2020 Dec]. Available from: http:// dmp.wa.gov.au/documents/Bulletins/MS_GMP_OH_MB5_ cyanidePoisoning.pdf.

5. Robinson J, Greene S. Cyanide Poisoning Antinode Kits. Melbourne: Victorian Poisons Information Centre; 2010.

6. Hilson G, Pardie S. Mercury: An Agent of Poverty in Ghana's Smallscale Gold Mining Industry? Resour Policy. 2006 Jun;31(2):106-16.

7. Establishing Small-Scale Mining as a New Dimension in Mineral Development, P. D. 1899 (January 23, 1984).

8. Hinton JJ, Veiga MM, Veiga ATC. Clean Artisanal Gold Mining: A Utopian Approach? J Clean Prod. 2003 Mar;11(2):99-115.

9. Veiga MM. Introducing New Technologies for Abatement of Global Mercury Pollution in Latin America [Internet]. Rio de Janeiro: UNIDO/UBC/CETEM/CNPq; 1997 [cited 2020 Dec]. Available from: https://www.ais.unwater.org/ais/aiscm/getprojectdoc. php?docid $=409$.

10. Saarkoppel' LM, Rushkevich OP, Kir'iakov VA, Sineva EL, Kazantsev DP. Occupational Hazards in Metal Mining Industry. Vestn Ross Akad Med Nauk. 2005;(3):39-42.

11. Hatheway AW. Mining and its Impact on the Environment by Fred G. Bell and Laurance J. Donnelly. Environ Eng Eng Geosci. 2007; 13(3):270-2. 
12. Philippine Statistics Authority. Mineral Resources [Internet]. Quezon City: Philippine Statistics Authority; c2021 [updated 2016; cited 2020 Dec]. Available from: https://psa.gov.ph/content/mineral-resources.

13. Australian Trade and Investment Commission [Internet]. Sydney: Australian Trade and Investment Commission; c2020 [cited 2020 Dec]. Available from: https://www.austrade.gov.au/australian/export/ export-markets/countries/philippines/industries/mining.

14. Mines and Geosciences Bureau - Department of Environment and Natural Resources. MINING INDUSTRY AT A GLANCE [Internet]. 2020 [cited $2021 \mathrm{Jan}$ ]. Available from: https://mgb.gov.ph/ images/Mineral_Statistics/mining_facts_and_figures_updated_22_ June_2020_final.pdf.

15. Revilla RC. Health in the Workplace: Examining the Contribution of Organization Factors on the Occurrence of Musculoskeletal Diseases in the Philippines. Quezon City: Philippine Statistics Authority; 2019 [cited $2021 \mathrm{Jan}$ ]. Available from: https://psa.gov.ph/sites/default/ files $/ 5.2 .3 \% 20$ Health\%20in\%20the\%20Workplace\%20Examining $\% 20$ the $\% 20$ Contribution $\% 20$ of $\% 20$ Organizational $\% 20$ Factors $\% 20$ on $\% 20$ the $\% 20$ Occurrence $\% 20$ of $\% 20$ Musculoskeletal.pdf.

16. Atakora M, Stenberg B. Assessment of Workers' Knowledge and Views of Occupational Health Hazards of Gold Mining in Obuasi Municipality, Ghana. Int J Occup Safety Health. 2020 Jul 05;10(1): 38-52.

17. Granadillos NG, Parafina C. Assessment of Occupational Safety and Health Hazards Exposure of Workers in Small-scale Gold Mining in the Philippines [Internet]. Makati City: International Labour Organization; 2020 [cited 2021 Jan]. Available from: http:// ilo.ch/wcmsp5/groups/public/---asia/---ro-bangkok/---ilo-manila/ documents/publication/wcms_751885.pdf.

18. Pascual LJH, Domingo SN, Manejar AJA. Answering Critical Questions on Mining in the Philippines: Phase 2 [Internet]. Quezon City: Philippine Institute for Development Studies; 2019 [cited 2021 Jan]. Available from: https://pidswebs.pids.gov.ph/CDN/ PUBLICATIONS/pidsdps1922.pdf.

19. People's Small-scale Mining Act of 1991, R. A. No. 7076 (June 27, 1991).

20. International Labour Organization. Health and safety at work: A trade union priority [Internet]. 2002 [cited 2020 Dec]. Available from: https://www.ilo.org/wcmsp5/groups/public/---ed_dialogue/---actrav/ documents/publication/wcms_111465.pdf.

21. Bland D, Bour A, Feldkamp D. Mining safety culture built on real leadership [Internet]. London: Aspermont Media Ltd.; c2000-2021 [updated 2020 July 24; cited 2020 Jan]. Available from: https:// www.mining-journal.com/forum/opinion/1391634/mining-safetyculture-built-on-real-leadership.

22. Stewart AG. Mining is Bad for Health: A Voyage of Discovery. Environ Geochem Health. 2019 Jul 09;42:1153-65.

23. Haddaway NR, Cooke SJ, Lesser P, Macura B, Nilsson AE, Taylor JJ. Evidence of the Impacts of Metal Mining and the Effectiveness of Mining Mitigation Measures on Social-ecological Systems in Arctic and Boreal Regions: A Systematic Map Protocol. Environ Evid. 2019 Feb 21;8:9.

24. Rebello S, Anoopkumar AN, Aneesh EM, Sindhu R, Binod P, Kim SH, Pandey A. Hazardous Minerals Mining: Challenges and Solutions. J Hazard Mater. 2021 Jan 15;402:123474. PubMed PMID: 32738780 .

25. International Occupational Health and Safety and Development. Mining in the Philippines and the Effects on Occupational Health and Safety of Mine Workers [Internet]. 1997 [cited 2020 Dec]. Available from: www.iohsad.org/.

26. Bansah KJ, Dumakor-Dupey NK, Kansake BA, Assan E, Bekui P. Socioeconomic and Environmental Assessment of Informal Artisanal and Small-scale Mining in Ghana. J Clean Prod. 2018 Nov 20;202:465-75.

27. Coehlo PCS, Teixeira JPF, Gonçalves ONBSM. Mining Activities: Health Impacts. Encyclopedia Environ Health. 2011;3:788-802.

28. Safe Drinking Water Foundation [Internet]. Saskatoon: Safe Drinking Water Foundation; c2020 [cited 2020 Dec]. Mining and Water
Pollution' [about 3 screens]. Available from: https://www.safewater. org/fact-sheets-1/2017/1/23/miningandwaterpollution.

29. Jaishankar M, Tseten T, Anbalagan N, Mathew BB, Beeregowda KN. Toxicity, Mechanism and Health Effects of Some Heavy Metals. Interdiscip Toxicol. 2014 Jun;7(2):60-72.

30. Macháček J. Typology of Environmental Impacts of Artisanal and Small-Scale Mining in African Great Lakes Region. Sustainability. 2019 May 19;11:3027.

31. Elgstrand K, Vingård E. Occupational Safety and Health in Mining [Internet]. Gothenburg: University of Gothenburg \& authors; 2013 [cited 2021 Jan]. Available from: https://gupea.ub.gu.se/ bitstream/2077/32882/1/gupea_2077_32882_1.pdf.

32. Winmore K, Tafadzwa Zhou. Occupational Hazards, Injuries and Illnesses associated with small scale gold mining: A Case of Ward 19, Zvishavane, Zimbabwe. The Dyke. 2014;8.1:41-62.

33. Long RN, Sun K, Neitzel RL. Injury Risk Factors in a Small-Scale Gold Mining Community in Ghana's Upper East Region. Int J Environ Res Public Health. 2015 Jul 24;12(8):8744-61.

34. Kyeremateng-Amoah E, Clarke EE. Injuries among Artisanal and Small-Scale Gold Miners in Ghana. Int J Environ Res Public Health. 2015 Sep 02;12(9):10886-96.

35. Duarte J, Baptista JS, Marques T. Occupational Accidents in the Mining Industry - A Short Review. In: Azeres P, et al., editors. Occupational and Environmental Safety and Health. Studies in Systems, Decision and Control, vol 202. New York City: Springer, Cham; 2019. p. 61-9.

36. Quitasol A. Four Small-Scale Miners Die of Suffocation [Internet]. Quezon City: Bulatlat.com; c2016 [updated 2010 Jun 26; cited 2021 Jan]. Available from: https://www.bulatlat.com/2010/06/26/30080/.

37. Mines and Communities. Philippine Mining Company Blamed for Worker's Tragedy [Internet]. London: Mines and Communities; c2013 [updated 2008 Sep 29; cited $2021 \mathrm{Jan}$ ]. Available from: http://www. minesandcommunities.org/article.php? $\mathrm{a}=8835$.

38. Manza M. The Resiliency of the Philippine Small-Scale Mining Communities: Bayanihan Amidst Super Typhoons and a Pandemic [Internet]. 2020 Dec 24 [cited 2021 Feb]. Available from: https:// www.planetgold.org/resiliency-philippine-small-scale-miningcommunities.

39. Ramo LV. Mankayan Awaits Worse Tragedy [Internet]. Quezon City: Bulatlat.com; c2016 [updated 2009 Jul 18; cited 2021 Feb]. Available from: https://www.bulatlat.com/2009/07/18/mankayan-awaits-worsetragedy/.

40. Dumlao A. 2 Miners Killed in Landslide [Internet]. Mandaluyong City: Philstar Global Corp.; c2021 [Internet] [updated 2012 Aug 16; cited 2021 Feb]. Available from: https://www.philstar.com/ nation/2012/08/16/838612/2-miners-killed-landslide.

41. Reade MC, Davies SR, Morley PT, Dennett J, Jacobs IC; Australian Resuscitation Council. Review Article: Management of Cyanide Poisoning. Emerg Med Australas. 2012 Jun;24(3):225-38.

42. Vick JA, Froehlich HL. Studies of Cyanide Poisoning. Arch Int Pharmacodyn Ther. 1985 Feb;273(2):314-22.

43. Laitos JG. Cyanide, Mining and the Environment. Envt L Rev. 2013 Jul;30(3):869-948.

44. Earthworks [Internet]. Washington: Earthworks; c2019 [cited 2021 Feb]. Cyanide Use in Gold Mining; [about 3 screens]. Available from: https://www.earthworks.org/issues/cyanide/.

45. Taylor J, Roney N, Harper C; Agency for Toxic Substances and Disease Registry. Toxicological Profile for Cyanide [Internet]. Atlanta: Agency for Toxic Substances and Disease Registry; 2006 [cited 2021 Feb]. Available from: https://www.atsdr.cdc.gov/toxprofiles/tp8.pdf.

46. Marshall BG, Veiga MM, da Silva HAM, Guimarães JRD. Cyanide Contamination of the Puyango-Tumbes River Caused by Artisanal Gold Mining in Portovelo-Zaruma, Ecuador. Curr Environ Health Rep. 2020 Sep;7(3):303-10.

47. Occupational Safety and Health Center - Department of Labor and Employment. A Case Study of Children in Small-Scale Mining [internet]. 1998 [cited 2021 Feb]. Available from: https://oshc. dole.gov.ph/wp-content/uploads/2020/10/1998-A-Case-Study-ofChildren-in-Small-Scale-Mining-2.pdf. 
48. Knoblauch AM, Farnham A, Ouoba J, Zanetti J, Müller S, JeanRichard V, et al. Potential Health Effects of Cyanide Use in Artisanal and Small-scale Gold Mining in Burkina Faso. J Clean Prod. 2020 Apr 10;252:119689.

49. United Nations Environment Programme. Global Mercury Assessment 2013: Sources, Emissions, Releases and Environmental Transport [Internet]. Geneva: UNEP Chemicals Branch; 2013 [cited $2021 \mathrm{Feb}$ ]. Available from: https://wedocs.unep.org/handle/20.500.11822/7984.

50. Mambrey V, Rakete S, Tobollik M, Shoko D, Moyo D, Schutzmeier P, et al. Artisanal and Small-scale Gold Mining: A Cross-sectional Assessment of Occupational Mercury Exposure and Exposure Risk Factors in Kadoma and Shurugwi, Zimbabwe. Environ Res. 2020 May;184:109379. PubMed PMID: 32197122.

51. Green CS, Lewis PJ, Wozniak JR, Drevnick PE, Thies ML. A Comparison of Factors Affecting the Small-scale Distribution of Mercury from Artisanal Small-scale Gold Mining in a Zimbabwean Stream System. Sci Total Environ. 2019 Jan 10;647:400-10.

52. Cortes-Maramba N, Reyes JP, Francisco-Rivera AT, Akagi H, Sunio R, Panganiban LC. Health and Environmental Assessment of Mercury Exposure in a Gold Mining Community in Western Mindanao, Philippines. J Environ Manage. 2006 Oct;81(2):126-34.

53. Samaniego J, Gibaga CR, Tanciongco A, Rastrullo R. Total Mercury in Soils and Sediments in the Vicinity of Abandoned Mercury Mine Area in Puerto Princesa City, Philippines. Appl Sci. 2020 Jul 02;10(13):4599.

54. Rappler. Widespread Mercury Poisoning Recorded in 2 Palawan Villages [Internet]. Pasig City: Rappler Inc.; c2021 [updated 2017 Jun 10; cited $2021 \mathrm{Feb}$ ]. Available from: https://www.rappler.com/nation/ widespread-mercury-poisoning-puerto-princesa-villages-palawan.

55. Appleton JD, Weeks JM, Calvez JP, Beinhoff C. Impacts of Mercury Contaminated Mining Waste on Soil Quality, Crops, Bivalves, and Fish in the Naboc River area, Mindanao, Philippines. Sci Total Environ. 2006 Feb 1;354(2-3):198-211.

56. Køster-Rasmussen R, Westergaard ML, Brasholt M, Gutierrez R, Jørs E, Thomsen JF. Mercury Pollution from Small-Scale Gold Mining Can Be Stopped by Implementing the Gravity-Borax Method--A Two-Year Follow-Up Study from Two Mining Communities in the Philippines. New Solut. 2016 Feb;25(4):567-87.

57. Appel PW, Na-Oy L. The Borax Method of Gold Extraction for Small-Scale Miners. J Health Pollut. 2012 Jun;2(3):5-10.

58. Arthur C, Kang JN. Mercury-free Gold Mining Strengthens Women in the Philippines [Internet]. Vienna: United Nations Industrial Development Organization; c2021 [cited 2021 Apr]. Available from: https://www.unido.org/news/mercury-free-gold-mining-strengthenswomen-philippines.

59. Appel PWU, Andersen A, Na-Oy LD, Onos R. Introduction of Mercury-free Gold Extraction Methods to Medium-Scale Miners and Education of Health Care Providers to Reduce the use of Mercury in Sorata, Bolivia. J Health Pollut. 2015 Dec 21;5(9):12-7.

60. Ban Toxics!. The Price of Gold: Mercury Use and Current Issues Surrounding Artisanal and Small-Scale Gold Mining in the Philippines [Internet]. Quezon City: Ban Toxics!; 2011 Jun [cited 2021 Apr]. Available from: http://www.takagifund.org/admin/img/ sup/rpt_file20152.pdf.

61. Teschner B, Smith NM, Borillo-Hutter T, John ZQ, Wong TE. How Efficient are They Really? A Simple Testing Method of Small-scale Gold Miners' Gravity Separation Systems. Miner Eng. 2017;105: 44-51.

62. Commonwealth Scientific and Industrial Research Organization. Cyanide-free Gold Recovery [Internet]. Canberra: CSIRO; c2021 [updated $2021 \mathrm{Feb} 19$; cited $2021 \mathrm{Apr}$. Available from: https://www. csiro.au/en/work-with-us/industries/mining-resources/Processing/ Going-for-gold.

63. SGS Mineral Services. Thiosulphate Leaching - An Alternative to Cyanidation in Gold Processing [Internet]. 2008 [cited 2021 Apr]. Available from: https://www.sgs.com/-/media/global/documents/ flyers-and-leaflets/sgs-min-wa018-thiosulphate-leaching-alternativeto-cyanide-in-gold-processing-en-11.pdf.

64. Clean Earth Technologies. Thiosulphate-based Solution Replaces Cyanide in Gold Recovery Test at Menzies Gold Hub [Internet].
Singapore: Clean Earth Technologies; c2020 [updated 2019 Oct 19; cited $2021 \mathrm{Apr}$. Available from: https://www.cleanearth.tech/ thiosulphate-based-solution-replaces-cyanide-in-gold-recovery-test/.

65. World Health Organization. Artisanal and Small-scale Gold Mining and Health [Internet]. Geneva:World Health Organization; 2016 [cited $2021 \mathrm{Apr}$. Available from: https://apps.who.int/iris/bitstream/hand le/10665/247195/9789241510271-eng.pdf?sequence=1\&isAllowed=y.

66. Elgstrand K, Sherson DL, Jørs E, Nogueira C, Thomsen JF, Fingerhut M, et al. Safety and Health in Mining: Part 1. Occupational Health Southern Africa. 2017 May/Jun;23(3):10-20.

67. Plumlee GS, Durant JT, Morman SA, Neri A, Wolf RE, Dooyema CA, et al. Linking Geological and Health Sciences to Assess Childhood Lead Poisoning from Artisanal Gold Mining in Nigeria. Environ Health Perspect. 2013 Jun;121(6):744-50.

68. Gottesfeld P, Tirima S, Anka SM, Fotso A, Nota MM. Reducing Lead and Silica Dust Exposures in Small-Scale Mining in Northern Nigeria. Ann Work Expo Health. 2019 Jan 7;63(1):1-8.

69. Gottesfeld P, Meltzer G, Costello S, Greig J, Thurtle N, Bil K, et al. Declining Blood Lead Levels among Small-scale Miners Participating in a Safer Mining Pilot Programme in Nigeria. Occup Environ Med. 2019 Nov;76(11):849-53.

70. The World Bank [Internet]. Washington: The World Bank Group; c2021 [cited 2021 Apr]. Climate-Smart Mining: Minerals for Climate Action; [about 2 screens]. Available from: https://www.worldbank.org/ en/topic/extractiveindustries/brief/climate-smart-mining-mineralsfor-climate-action.

71. Philippine Council for Industry, Energy, and Emerging Technology Research and Development (DOST-PCIEERD). Green Mining Technology for the Small-Scale Mining Industry [Internet]. 2018 Mar [cited $2021 \mathrm{Apr}$. Available from: http://pcieerd.dost.gov.ph/images/ policy_advocacy/Policy-Brief-Mining-Itogon---PDF.pdf.

72. Regidor A. UPD Brings Green Mining to the Barrio [Internet]. Quezon City: UP Diliman Information Office; c2021 [updated 2017 Aug 14; cited 2021 Apr]. Available from: https://upd.edu.ph/updbrings-green-mining-to-the-barrio/?cli_action=1628161493.339.

73. Mones MJ. Safety and Working Conditions in Small-scale Mining: The Case of Selected Small-scale Metallic Mines in the Philippines [Internet]. Geneva: International Labour Organization; 2018 [cited 2021 Apr]. Available from: https://www.ilo.org/wcmsp5/groups/ public/---asia/---ro-bangkok/---ilo-manila/documents/publication/ wcms_668736.pdf.

74. Local Government Code of 1991, R. A. No. 7160 (October 10, 1991).

75. Doguiles DE. LGU Tboli Bans Use of Mercury in Gold Processing [Internet]. Quezon City: Philippine Information Agency; c2021 [updated 2019 Sep 17; cited 2021 Apr]. Available from: https://pia. gov.ph/news/articles/1027431.

76. Philippine Daily Inquirer. Cyanide Barred in Small-scale Mine in Itogon [Internet]. Makati City: INQUIRER.net; c1997-2021 [updated 2019 Jan 18; cited 2021 Apr]. Available from: https:// newsinfo.inquirer.net/1074410/cyanide-barred-in-small-scale-minein-itogon.

77. Cabreza V. Cyanide Turns River Blue in Benguet Mine Town [Internet]. Makati City: INQUIRER.net; c1997-2021 [updated 2017 Oct 19; cited 2021 Apr]. Available from: https://newsinfo. inquirer.net/939086/cyanide-turns-river-blue-in-benguet-mine-town.

78. Galvez JK, TMT. Ban Toxics, CamNorte sign MOU [Internet]. Manila City: The Manila Times; c2021 [updated 2015 Feb 11; cited 2021 Apr]. Available from: https://www.manilatimes.net/2015/02/11/ news/regions/ban-toxics-camnorte-sign-mou/162276/.

79. Bicol Standard Newspaper. CNorte Mercury Use Monitored [Internet]. Naga City: Bicol Standard Newspaper; c2021 [updated 2018 Jan 20; cited $2021 \mathrm{Apr}$. Available from: http://www.bicolstandard. com/2018/01/cnorte-mercury-use-monitored.html.

80. International Labour Organization. Child Labour in Mining, Poor Working Conditions Take Center Stage in Inter-regional Meeting [Internet]. Manila City: International Labour Organization; c19962021 [updated 2019 May 29; cited 2021 Apr]. Available from: https://www.ilo.org/manila/public/pr/WCMS_706334/lang--en/ index.htm. 
81. Ban Toxics. Camarines Norte, BAN Toxics and ILO Vow to End Child Labor in Mining [Internet]. Quezon City: Bantoxics; c2020 [updated 2017 Apr 26; cited 2021 Apr]. Available from: https://bantoxics.org/ news-and-updates/camarines-norte-ban-toxics-and-ilo-vow-to-endchild-labor-in-mining/.

82. Lacorte G. In South Cotabato, a Template for Small-scale Mining [Internet]. Makati City: INQUIRER.net; c1997-2021 [updated 2017 Dec 8; cited 2021 Apr 14]. Available from: https://newsinfo.inquirer. net/655683/in-south-cotabato-a-template-for-small-scale-mining.

83. Jacinto A. Zamboanga del Norte Slaps Ban on Open-pit Mining [Internet]. Manila City: The Manila Times; c2021 [updated 2011 Nov 03; cited $2021 \mathrm{Apr}$. Available from: https://www.manilatimes. net/2011/11/03/news/regions/zamboanga-del-norte-slaps-ban-onopen-pit-mining/745007/.

84. Agoot L. Benguet Town Forms Task Force vs. Illegal Mining [Internet]. Quezon City: Philippine News Agency; c2021 [updated 2019 Aug 09; cited 2021 Apr]. Available from: https://www.pna.gov. $\mathrm{ph} /$ articles/1077448.

85. CONST. Art. VII, § 2 (Phil.), (1987)

86. Chaloping-March M. The Mining Policy of the Philippines and «Resource Nationalism» towards Nation-building. J Soc Océan. 2014. 138-139:93-106.

87. Philippine Mining Act of 1995, R. A. No. 7942 (March 3, 1995).

88. Bureau of Labor Relations - Department of Labor and Employment [Internet]. Manila City: Bureau of Labor Relations; c2021 [cited 2021 Apr]. Labor Code of the Philippines; [about 1 screen]. Available from: https://blr.dole.gov.ph/2014/12/11/labor-code-of-the-philippines/.

89. Human Right Watch. "What... if Something Went Wrong?"Hazardous Child Labor in Small-Scale Gold Mining in the Philippines [Internet]. New York: Human Rights Watch; c2021 [updated 2015 Sep 29; cited 2021 Apr]. Available from: https://www.hrw.org/report/2015/09/29/ what-if-something-went-wrong/hazardous-child-labor-small-scalegold-mining\#_ftn102.

90. Toxic Substances and Hazardous and Nuclear Wastes Control Act of 1990, R. A. No. 6969 (October 26, 1990).

91. Department of Health [Internet]. Manila City: Department of Health; c2021 [cited 2021 Apr]. What is Clean Air Act?; [about 1 screen]. Available from: https://doh.gov.ph/faqs/What-is-the-Clean-Air-Act.

92. Aquino AP, Derequito JAP, Festejo-Abeleda MA. Ecological Solid Waste Management Act: Environmental Protection Through Proper Solid Waste Practice [Internet]. Taipei: FFTC; c2021 [updated 2013 Dec 09; cited 2021 Apr]. Available from: https://ap.fftc.org.tw/ article $/ 588$.

93. The Indigenous Peoples' Right Act of 1997, R. A. No. 8371 (October 29, 1997).
94. ICLG. Philipines: Mining Laws and Regulations 2021 [Internet]. London: ICLG.com; c2002-2021 [updated 2020 Oct 09; cited 2021 Apr]. Available from: https://iclg.com/practice-areas/mining-lawsand-regulations/philippines.

95. Basilio LR. DENR Issues Revised IRR of 'Small-scale Mining Act' [Internet]. Tuguegarao City: Mines and Geosciences Bureau Region 2; c2021 [updated 2015 Apr 14; cited 2021 Apr]. Available from: http://mgb2.com/index.php/33-home-page/32-mgb-bolsters-hiringpromotion-process\#: : text=from $\% 20$ the $\% 20$ Board.-,DAO $\% 20$ No.,effect\%20on\%20April\%202\%2C\%202015.

96. Bureau of Working Conditions - Department of Labor and Employment [Internet]. Manila City: Bureau of Working Conditions; c2021 [cited $2021 \mathrm{Apr}$. OSH Law; [about 1 screens]. Available from: https://bwc.dole.gov.ph/osh-law.

97. Nuñez MAC. Philippines EITI Scoping Study On Small-Scale Metallic Mining [Internet]. 2015 Dec [cited 2021 Apr]. Available from: https://eiti.org/document/philippines-eiti-scoping-study-onsmallscale-metallic-mining.

98. Clemente ED. Challenges in the Philippine Mining Industry [Internet]. Quezon City: Philippine Institute for Development Studies; 2019 May [cited $2021 \mathrm{Apr}$. Available from: https://thinkasia.org/handle/11540/10272.

99. Gankhuyag U, Gregoire F. Managing Mining for Sustainable Development: A Sourcebook [Internet]. Bangkok: United Nations Development Programme; 2018 [cited 2021 Apr]. Available from: https://www.undp.org/publications/managing-mining-sustainabledevelopment.

100. International Agreements on Environment and Natural Resources - Department of Environment and Natural Resources. Minamata Convention [Internet]. Quezon City: DENR Int'1 ENR Agreements; c2021 [updated 2019 Dec 23; cited 2021 Apr]. Available from: https://intl.denr.gov.ph/index.php/database-un-conventions/article/ 8-minamata-convention.

101. United Nations Environment Programme. MINAMATA CONVENTION ON MERCURY: FACT SHEET [Internet]. 2017 [cited $2021 \mathrm{Apr}$. Available from: https://www.mercuryconvention. org/Portals/11/documents/Awareness\%20raising/FACT\%20 SHEETS/Minamata\%20Convention\%20on\%20Mercury\%20at\%20 a\%20glance_COP1\%202017.pdf.

102. Segura-Salazar J, Tavares LM. Sustainability in the Minerals Industry: Seeking a Consensus on Its Meaning. Sustainability. 2018;10:1429.

103. Khanna T. Mining and the environmental agenda. Mining Magazine (UK). 1999;181(3):158-63. 